\title{
Development of an Amperometric Hydrogen Peroxide Biosensor based on the Immobilization of Horseradish Peroxidase onto Nickel Ferrite Nanoparticle-Chitosan Composite
}

Furkan Yalçıner, Emre Çevik, Mehmet Şenel*, Abdülhadi Baykal

(Received 12 May 2011; accepted 27 June 2011; published online 1 July 2011.)

\begin{abstract}
Nickel ferrite $\left(\mathrm{NiFe}_{2} \mathrm{O}_{4}\right)$ nanoparticles have been dispersed in chitosan solution in order to fabricate nanocomposite films. Horseradish peroxidase (HRP) has been immobilized onto this chitosan- $\mathrm{NiFe}_{2} \mathrm{O}_{4}$ nanocomposite film via physical adsorption. The size of the $\mathrm{NiFe}_{2} \mathrm{O}_{4}$ nanoparticles has been estimated using X-ray diffraction pattern and scanning electron microscopy (SEM) to be $40 \pm 9 \mathrm{~nm}$. The chitosan- $\mathrm{NiFe}_{2} \mathrm{O}_{4}$ nanocomposite film and $\mathrm{HRP} /$ chitosan- $\mathrm{NiFe}_{2} \mathrm{O}_{4}$ bioelectrode have been characterized using SEM technique. The $\mathrm{HRP} /$ chitosan- $\mathrm{NiFe}_{2} \mathrm{O}_{4}$ nanocomposite bioelectrode has a response time of $4 \mathrm{~s}$, linearity as 0.3 to $12 \mathrm{mM}$ of $\mathrm{H}_{2} \mathrm{O}_{2}$, sensitivity as $22 \mathrm{nA} / \mathrm{mM}$. The effects of $\mathrm{pH}$ and the temperature of the immobilized HRP electrode have also been studied.
\end{abstract}

Keywords: Biosensor; $\mathrm{NiFe}_{2} \mathrm{O}_{4}$; Horseradish peroxidase; Nanoparticle; Chitosan

Citation: Furkan Yalçıner, Emre Çevik, Mehmet Şenel and Abdülhadi Baykal, "Development of an Amperometric Hydrogen Peroxide Biosensor based on the Immobilization of Horseradish Peroxidase onto Nickel Ferrite Nanoparticle-Chitosan Composite", Nano-Micro Lett. 3 (2), 91-98 (2011). http://dx.doi.org/10.3786/nml. v3i2.p91-98

\section{Introduction}

The rapid, accurate, reliable and reagentless sensing and detection of hydrogen peroxide is of great importance in textile/food and health care industries. Many techniques, including titrimetry [1], chemiluminescence [2], fluorescence [3] and spectrophotometry [4], tend to be complex, time-consuming and suffer from various interferences. Consequently, rapid and reliable methods for measuring $\mathrm{H}_{2} \mathrm{O}_{2}$ are greatly sought after. Electrochemical methods, especially using various amperometric $\mathrm{H}_{2} \mathrm{O}_{2}$ biosensors, have been extensively employed for the detection of $\mathrm{H}_{2} \mathrm{O}_{2}$. Several valuable efforts have been focused on the development of electrochemical biosensors based on horseradish peroxidase for the detection of $\mathrm{H}_{2} \mathrm{O}_{2}$. The performance of these biosen- sors depends on the methods of enzyme immobilization when fabricating enzyme-modified electrodes. Various immobilization techniques have been employed, including adsorption [5], cross-linking [6], layer-by-layer assembly [7], covalent binding [8], surfactant-enzyme complex formation [9], sol-gel entrapment [10], and the use of biological membranes [11] and nanomaterials [12].

Magnetic nanoparticles as special biomolecule immobilizing carriers are becoming the focus of research [13]. Magnetic nanoparticles have been used in biomedicine and immunology due to its special properties [1416]. The applications of magnetic nanoparticles in the immobilization of biomolecules have been studied by Kaushik et al. [17] and Qu et al. [18]. Among magnetic nanoparticles, ferrites are a broad class of complex

Department of Chemistry, Faculty of Arts and Sciences, Fatih University, B. Cekmece, Istanbul 34500, Turkey

*Corresponding author. E-mail: msenel@fatih.edu.tr 
magnetic oxides of considerable technological importance $[19,20]$. Nickel ferrite $\left(\mathrm{NiFe}_{2} \mathrm{O}_{4}\right)$, with an inverse spinel structure shows good biocompatibility, noncytotoxicity, easy preparation and also ferromagnetism that originates from magnetic moment of anti-parallel spins between $\mathrm{Fe}^{3+}$ ions at tetrahedral sites and $\mathrm{Ni}^{2+}$ ions at octahedral sites [21, 22]. Due to their large surface-tovolume ratio, high surface reaction activity, high catalytic efficiency and strong adsorption ability, nanomaterials are utilized for biosensor applications. In a recent study, Luo et al. used chitosan $/ \mathrm{NiFe}_{2} \mathrm{O}_{4}$ nanocomposite as an enzyme immobilization matrix for glucose biosensor application [23]. This study shows that GOx incorporated chitosan $/ \mathrm{NiFe}_{2} \mathrm{O}_{4}$ nanocomposite is characteristic by an excellent electroanalytical response to glucose.

Due to the excellent film-forming ability, high permeability, mechanical strength, nontoxicity, biocompatibility, low cost and availability, chitosan has been found to be a workhorse biopolymer for the immobilization of biomolecules for biosensor applications. Much effort has been made to improve the performance of chitosan for application as biosensors. These adjustments include its structural modification, change in molecular factors, as well as the incorporation of metal oxide nanoparticles in the chitosan network structure [24, 25].

The motivation of our work is to construct and analyze a simple biosensor using HRP for the detection of hydrogen peroxide. Optimized experimental conditions for the fabrication and operation of the biosensor have been established. The resulting biosensor has some advantages such as high sensitivity, good repeatability and reproducibility.

\section{Materials and methods}

\section{Materials}

HRP (EC 1.11.1.7, RZ>3.0, $250 \mathrm{U} / \mathrm{mg}$ ), and chitosan were obtained from Sigma. All other chemicals were of analytical grade and used without further purification.

\section{Preparation of $\mathrm{NiFe}_{2} \mathrm{O}_{4}$ nanoparticles}

Nanoparticles of $\mathrm{NiFe}_{2} \mathrm{O}_{4}$ were prepared through microwave-induced combustion. Analytical grade $1 \mathrm{~g} \quad \mathrm{NiCl}_{2}, \quad 1 \mathrm{~g} \quad \mathrm{Fe}\left(\mathrm{NO}_{3}\right)_{2}$, and with $1 \mathrm{~g}$ glycine $\left(\mathrm{NH}_{2} \mathrm{CH}_{2} \mathrm{COOH}\right)$, were dissolved in deionized water in the desired ratio. The crucible containing the solution was heated in a microwave oven (CEM, MDS 81D, $650 \mathrm{~W}$ ). Initially, the solution boils and evaporates followed by decomposition with copious evolution of gases $\left(\mathrm{N}_{2}, \mathrm{NO}_{2}, \mathrm{CO}_{2}\right)$. When the mixture reaches the ignition temperature it begins burning and releases a great deal of heat from the highly exothermic reaction [26]. This vaporizes the remaining liquid instantly, and forms a solid burning at over $1000^{\circ} \mathrm{C}$. The entire process takes only 15 min to produce ferrite powders. Glycine serves as fuel, being oxidized by nitrate. The evolution of large amounts of gases helps dissipate heat, reducing oxide sintering $[27,28]$.

\section{Preparation of $\mathrm{NiFe}_{2} \mathrm{O}_{4} /$ Chitosan solution}

Chitosan solution $(0.5 \%)$ was obtained by dissolving $0.025 \mathrm{~g}$ of chitosan in $5 \mathrm{ml}$ of $0.05 \mathrm{~mol} \cdot \mathrm{l}^{-1}$ acetate buffer solution (acetate dissolved in doubly distilled water). The calculated amount of $\mathrm{NiFe}_{2} \mathrm{O}_{4}$ nanoparticles was dispersed in the chitosan solution by stirring at room temperature, followed by sonification. Finally, a highly viscous solution of chitosan with uniformly dispersed $\mathrm{NiFe}_{2} \mathrm{O}_{4}$ nanoparticles was obtained.

\section{Construction of $\mathrm{HRP} / \mathrm{NiFe}_{2} \mathrm{O}_{4} /$ chitosan biosen- sor}

Before each experiment, the GCE (3 mm diameter) was first polished on chamois leather with $0.05 \mu \mathrm{m}$ alumina powders and then washed ultrasonically in doubly distilled water, anhydrous ethanol, and water, respectively. After these pretreatments, the cleaned GCE was dried in air. $\mathrm{HRP} / \mathrm{NiFe}_{2} \mathrm{O}_{4} /$ chitosan solution was prepared by mixing $\mathrm{HRP}$ in $\mathrm{NiFe}_{2} \mathrm{O}_{4} /$ chitosan solution. To get the best amperometric responses of the biosensor, the composition of the $\mathrm{HRP} / \mathrm{NiFe}_{2} \mathrm{O}_{4} /$ chitosan were optimized. $10 \mu \mathrm{l}$ of solution was dropped on the surface of the cleaned GCE. Then the electrode was dried at room temperature. Before experiment, the biosensor was immersed in $0.1 \mathrm{mM}$ PBS $(\mathrm{pH}=8)$ to wash out the non-immobilized components from the electrode surface. When not in use, the biosensor was preserved at $4^{\circ} \mathrm{C}$ in a dry state.

\section{Apparatus and measurements}

X-ray powder diffraction (XRD) analysis was conducted on a Rigaku Smart Lab operated at $40 \mathrm{kV}$ and $35 \mathrm{~mA}$ using $\mathrm{Cu} \mathrm{K} \alpha$ radiation $(\lambda=1.54059 \AA)$. FEI XL40 Sirion FEG Digital Scanning Microscope was used in order to investigate the microstructure and morphology of the sample. Samples were coated with gold at $10 \mathrm{~mA}$ for $2 \mathrm{~min}$ prior to the scanning electron microscopy (SEM) analysis.

All electrochemical measurements were performed using a CHI Model 842B electrochemical analyzer. These measurements were carried out using a three electrode cell with glassy carbon electrode as the working electrode, a platinum $(\mathrm{Pt})$ wire as the counter electrode, and saturated $\mathrm{Ag} / \mathrm{AgCl}$ electrode as a reference electrode in phosphate buffer saline (PBS, $10 \mathrm{mM}, \mathrm{pH}$ 8) containing $\left[\mathrm{Fe}(\mathrm{CN})_{6}\right]^{3-/ 4-}$. All amperometric measurements were carried out at room temperature. They were performed in stirred solutions by applying the de- 
sired potential and allowing the steady state current to be reached. Once prepared, the enzyme electrode were immersed in $10 \mathrm{ml}$ of a $10 \mathrm{mM} \mathrm{PBS}, \mathrm{pH} 8$ solution, and the amperometric responses to the addition of known amount of analyte solution were recorded, respectively. The data are the average of three measurements.

\section{Results and Discussion}

\section{Construction of $\mathrm{HRP} / \mathrm{NiFe}_{2} \mathrm{O}_{4} /$ chitosan nano- biocomposite}

The XRD powder patterns (Fig. 1(a)) of the prepared samples exhibited the reflection planes $\left(\begin{array}{lll}1 & 1 & 1\end{array}\right)$,

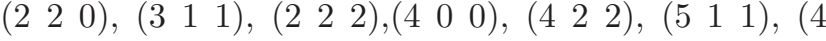
$40),(620),(533)$ and $(622)$ that indicate the presence of the spinel cubic structure matching well with the powder diffraction File No.10-325 [29,30]. The mean size of the crystallites was estimated from the diffraction pattern by line profile fitting method using Eq. (1) given in reference 31 and reference 32 [31, 32]. The line profile, shown in Fig. 1, was fitted for above eleven peaks. The average crystallite size, D, was obtained as $40 \pm 9 \mathrm{~nm}$ as a result of this line profile fitting. Figure 1(b) shows that the as-synthesized $\mathrm{NiFe}_{2} \mathrm{O}_{4}$ NPs have large grain structures. The material becomes highly dense and large particles of $1 \mu \mathrm{m}$ are observed. The material is of a spongy nature with struts.

The porous film of chitosan contains pin holes as illustrated by the SEM micrograph in Fig. 2(a). Figure 2(b) shows that $\mathrm{NiFe}_{2} \mathrm{O}_{4}$ nanoparticles are uniformly embedded in the porous $\mathrm{CH}$ network. The surface of
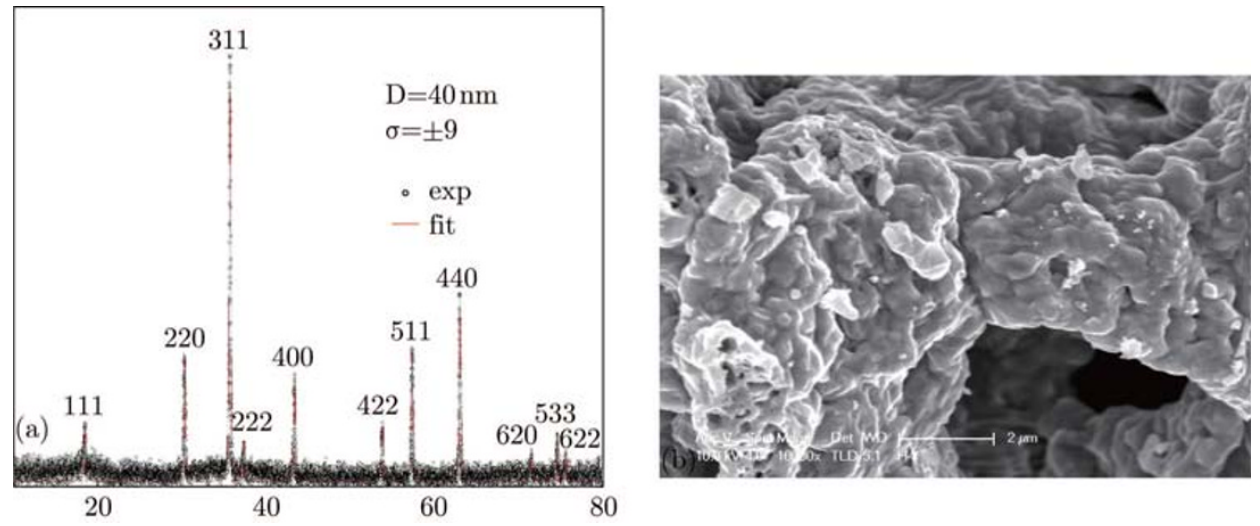

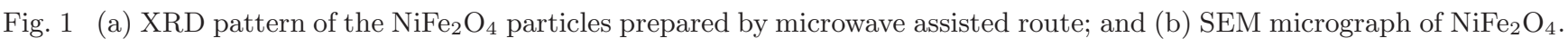
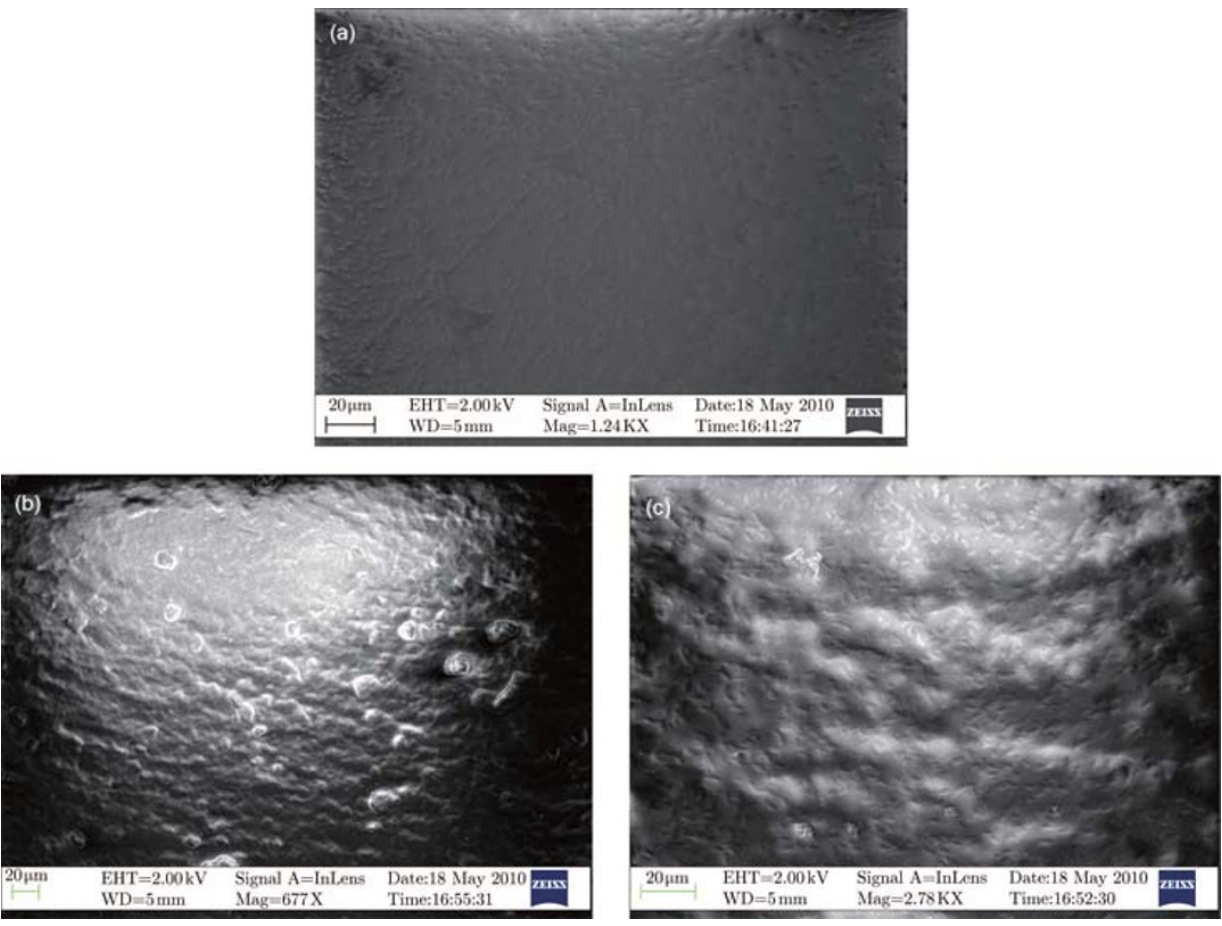

Fig. 2 (a) SEM micrographs of chitosan; (b) $\mathrm{NiFe}_{2} \mathrm{O}_{4} /$ chitosan; and (c) $\mathrm{HRP} / \mathrm{NiFe}_{2} \mathrm{O}_{4} /$ chitosan. 
HRP immobilized $\mathrm{NiFe}_{2} \mathrm{O}_{4}$ chitosan nanocomposite shows a homogeneous globular morphology (pocks due to the presence of HRP immobilized $\mathrm{NiFe}_{2} \mathrm{O}_{4}$ in chitosan can be clearly observed) (Fig. 2(c)) revealing the immobilization of HRP.

\section{Electrochemical behavior of $\mathrm{HRP} / \mathrm{NiFe}_{2} \mathrm{O}_{4} /$ chitosan modified electrode}

Electrochemical impedance spectroscopy (EIS) studies of chitosan film, $\mathrm{NiFe}_{2} \mathrm{O}_{4} /$ chitosan and $\mathrm{HRP} /$ $\mathrm{NiFe}_{2} \mathrm{O}_{4} /$ chitosan bioelectrodes have been conducted in the frequency range of $0.01-10^{5} \mathrm{~Hz}$. In the EIS investigation, the semicircle part corresponds to the electron transfer limited process; its diameter is equal to the electron transfer resistance, $\mathrm{R}_{C T}$, which controls the electron transfer kinetics of the redox probe at the electrode interface. Figure 3 presents the representative impedance spectrum of the (a) Bare GCE, (b) chitosan, (c) $\mathrm{NiFe}_{2} \mathrm{O}_{4} /$ chitosan, (d) $\mathrm{HRP} / \mathrm{NiFe}_{2} \mathrm{O}_{4} /$ chitosan and (e) $\mathrm{HRP} /$ chitosan electrodes in $10 \mathrm{mM}$ PBS $\mathrm{pH}=8.5$ solution, containing $\left[\mathrm{Fe}(\mathrm{CN})_{6}\right]^{3-/ 4-}(5 \mathrm{mM})$, respectively. It can be seen that the bare GCE exhibits an almost straight line that is characteristic of a diffusion limiting step of the electrochemical process. A welldefined semicircle curve was observed with both the chitosan film electrode (curve b) and $\mathrm{NiFe}_{2} \mathrm{O}_{4} /$ chitosan nanocomposite film electrode (curve c). It indicates the impedance of the electrode increases in the presence of $\mathrm{NiFe}_{2} \mathrm{O}_{4} /$ chitosan nanocomposite and chitosan film due to the non-conductivity of chitosan component in the film, which obstructed the electron transfer of the $\mathrm{Fe}(\mathrm{CN})_{6}^{3-/ 4-}$. The impedance of $\mathrm{NiFe}_{2} \mathrm{O}_{4} /$ chitosan nanocomposite film is smaller than that of chitosanGCE. This decreased impedance can be attributed to the conductivity of $\mathrm{NiFe}_{2} \mathrm{O}_{4}$ nanoparticles. An obvious

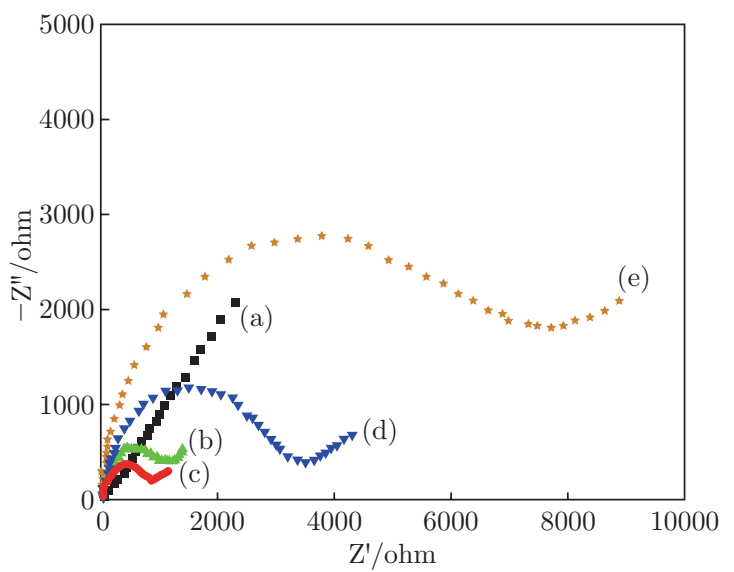

Fig. 3 Electrochemical impedance spectra of: (a) Bare GCE; (b) chitosan; (c) $\mathrm{NiFe}_{2} \mathrm{O}_{4} /$ chitosan; (d) $\mathrm{HRP} / \mathrm{NiFe}_{2} \mathrm{O}_{4} /$ chitosan; and (e) $\mathrm{HRP} /$ chitosan electrodes in $10 \mathrm{mM}$ PBS solution containing $\left[\mathrm{Fe}(\mathrm{CN})_{6}\right]^{3-/ 4-}(5 \mathrm{mM})$ $(\mathrm{pH}=8.5)$. increase in the interfacial resistance can be observed when $\mathrm{HRP}$ is entrapped in the $\mathrm{NiFe}_{2} \mathrm{O}_{4}$ /chitosan film. The increase of $\mathrm{R}_{c t}$ might have been caused by the hindrance of the macromolecular structure of HRP to the electron transfer. On the other hand, $\mathrm{R}_{c t}$ of $\mathrm{HRP} / \mathrm{NiFe}_{2} \mathrm{O}_{4} /$ chitosan is smaller than that of $\mathrm{HRP} /$ chitosan, indicating the $\mathrm{HRP} / \mathrm{NiFe}_{2} \mathrm{O}_{4} /$ chitosan nanocomposite film allows greater permeation for $\mathrm{Fe}(\mathrm{CN})_{6}^{3-/ 4-}$ probe than the pure chitosan film.

Figure 4 shows various cyclic voltammogrammes
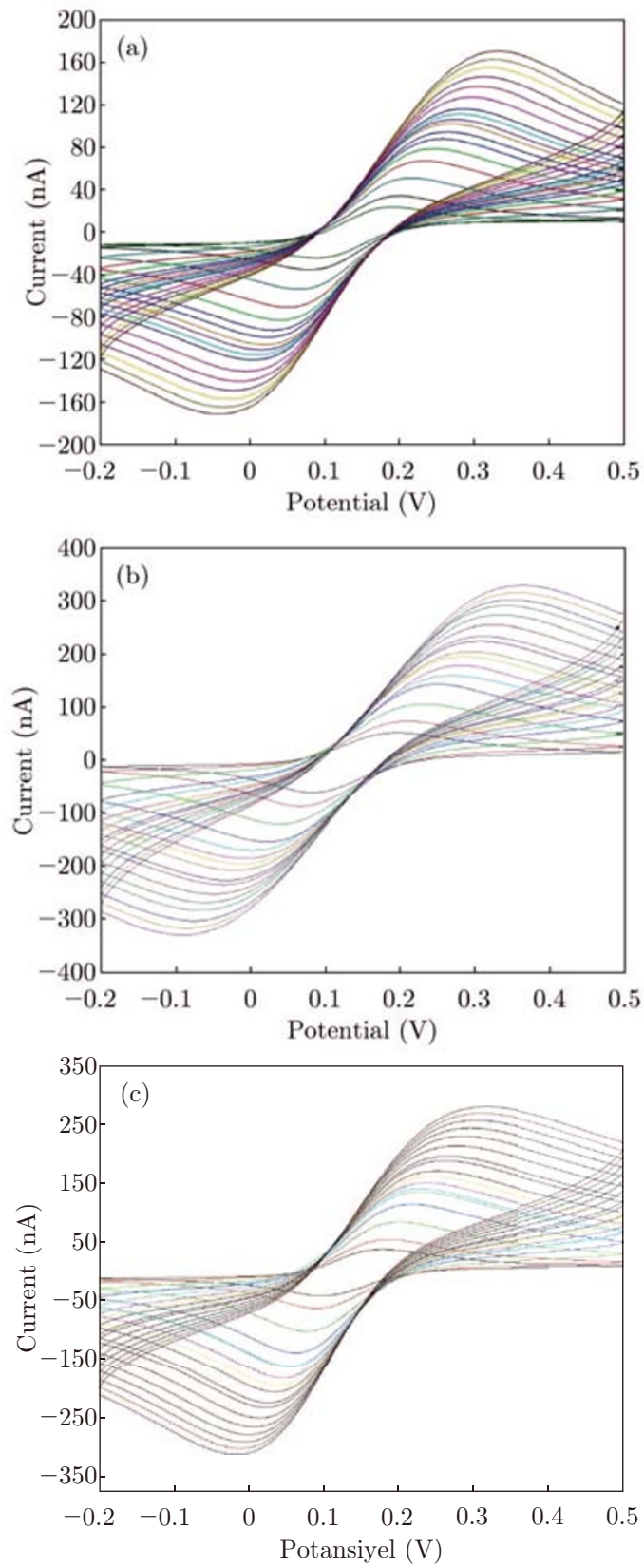

Fig. 4 CVs of: (a) chitosan; (b) $\mathrm{NiFe}_{2} \mathrm{O}_{4} /$ chitosan; and (c) $\mathrm{HRP} / \mathrm{NiFe}_{2} \mathrm{O}_{4} /$ chitosan electrodes in $10 \mathrm{mM}$ PBS solution containing $\left[\mathrm{Fe}(\mathrm{CN})_{6}\right]^{3-/ 4-}(10 \mathrm{mM})$ at $10-100 \mathrm{mV} \cdot \mathrm{s}^{-1}$ (from inner to outer). 
obtained for (a) chitosan, (b) $\mathrm{NiFe}_{2} \mathrm{O}_{4} /$ chitosan and (c) $\mathrm{HRP} / \mathrm{NiFe}_{2} \mathrm{O}_{4} /$ chitosan electrodes in $10 \mathrm{mM} \mathrm{PBS}$ solution containing $\left[\mathrm{Fe}(\mathrm{CN})_{6}\right]^{3-/ 4-}(10 \mathrm{mM})$, at $10-$ $100 \mathrm{mV} \cdot \mathrm{s}^{-1}$. It can be seen that the anodic potential shifts towards positive side and the cathodic peak potential shifts in the reverse direction. Besides this, the redox peak currents are proportional to the square root of scan rate, $v_{1 / 2}$, indicating a diffusion electrontransfer process. it can be seen that the redox potential of $\mathrm{NiFe}_{2} \mathrm{O}_{4} /$ chitosan electrode shifts towards the higher side than that of pure chitosan film due to the incorporation of $\mathrm{NiFe}_{2} \mathrm{O}_{4}$ nanoparticles. It appears that the $\mathrm{NiFe}_{2} \mathrm{O}_{4} /$ chitosan nanocomposite electrode provides a biocompatible environment to the HRP; and $\mathrm{NiFe}_{2} \mathrm{O}_{4}$ nanoparticles act as an electron mediator resulting in an accelerated electron transfer between HRP and electrode [33].

The electrocatalytic behavior of HRP incorporated in the bionanocomposite has been evaluated by cyclic voltammetry. Since the proposed HRP electrode did not show direct electron transfer between immobilized HRP and GCE, $\mathrm{K}_{4} \mathrm{Fe}(\mathrm{CN})_{6}$ was used as the electron mediator. Cyclic voltammograms $(\mathrm{CVs})$ of the $\mathrm{HRP} / \mathrm{CS} / \mathrm{GPTMS}$-modified electrode in $0.02 \mathrm{~mol} \cdot \mathrm{l}^{-1}$ PBS $(\mathrm{pH}=7.0)$ are shown in Fig. 5. When $40 \mu \mathrm{mol} \cdot \mathrm{l}^{-1}$ $\mathrm{H}_{2} \mathrm{O}_{2}$ was introduced, an obvious electrocatalytic response was observed with the increase of reduction current and the decrease of oxidation current. The response process of the biosensor may be expressed as follows:

$$
\mathrm{H}_{2} \mathrm{O}_{2}+2 \mathrm{Fe}(\mathrm{CN})_{6}^{4-}+2 \mathrm{H}^{+} \stackrel{\mathrm{HRP}}{\longrightarrow} 2 \mathrm{H}_{2} \mathrm{O}+2 \mathrm{Fe}(\mathrm{CN})_{6}^{3-}
$$

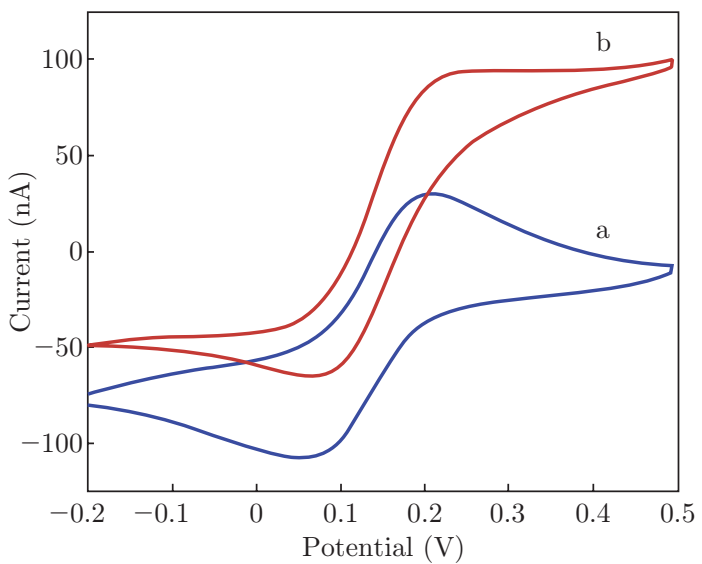

Fig. 5 CVs of the HRP/CS/GPTMS-modified electrode in $0.02 \mathrm{~mol} \cdot \mathrm{l}^{-1} \mathrm{PBS}(\mathrm{pH}=8.0)$ containing $\left[\mathrm{Fe}(\mathrm{CN})_{6}\right]^{3-/ 4-}$ $(10 \mathrm{mM})$ at a scan rate of $50 \mathrm{mV} \cdot \mathrm{s}^{-1}$ (a) without $\mathrm{H}_{2} \mathrm{O}_{2}$; and (b) with $5 \mathrm{mmol} \cdot \mathrm{l}^{-1} \mathrm{H}_{2} \mathrm{O}_{2}$.

\section{Optimization experimental parameters}

The amount of the enzyme in composite is a vital factor affecting the analytical sensitivity of the biosensor
(Fig. 6(a)). By the use of composite solutions containing different $\mathrm{HRP}$ concentrations and a fixed $\mathrm{NiFe}_{2} \mathrm{O}_{4}$ concentration $\left(2 \mathrm{mg} \cdot \mathrm{ml}^{-1}\right)$ for dropping on the surface of the GCE, the change of amperometric current with HRP amount under constant $\mathrm{H}_{2} \mathrm{O}_{2}$ concentration is shown in Fig. 6. The current response increases as increasing HRP concentration and achieves a maximum value at $8.0 \mathrm{mg} \cdot \mathrm{ml}^{-1}$. With the increasing of HRP concentration from 8.0 to $10.0 \mathrm{mg} \cdot \mathrm{ml}^{-1}$, the sensitivity reduces gradually. So, an optimum loading of $8.0 \mathrm{mg} \cdot \mathrm{ml}^{-1} \mathrm{HRP}$ was used for subsequent experiments.

Figure 6(b) shows the dependence of the current response of the modified electrode on the applied potential in the range from $-0.3 \mathrm{~V}$ to $0 \mathrm{~V}$ under constant $\mathrm{H}_{2} \mathrm{O}_{2}$ concentration. With applied potential decreasing from $-0.1 \mathrm{~V}$ to $0 \mathrm{~V}$, the steady state current increases due to the increased driving force for the fast reduction of $\mathrm{H}_{2} \mathrm{O}_{2}$ at the lower potentials and approaches a maximum value at $-0.1 \mathrm{~V}$, then the response current decreases with applied potential decreasing from $-0.3 \mathrm{~V}$ to $-0.1 \mathrm{~V}$. Therefore, $-0.1 \mathrm{~V}$ was selected as the applied potential for amperometric measurement in subsequent experiments.

The effect of $\mathrm{pH}$ on the modified electrode response was investigated under constant $\mathrm{H}_{2} \mathrm{O}_{2}$ concentration and the results are displayed in Fig. 6(c). The biosensor response increases with increasing $\mathrm{pH}$ value from 5.0 to 8.0 , and achieves a maximum value at 8.0, then decreases from 8.0 to 9.0. So $\mathrm{pH}=8.0 \mathrm{PBS}$ was chosen as the supporting electrolyte for the further experiments.

The activity of the enzyme electrode has been investigated using $15 \mathrm{mM} \mathrm{H} \mathrm{H}_{2} \mathrm{O}_{2}$ solution in $10 \mathrm{mM}$ PBS, $\mathrm{pH}=8.0$ solution by amperometric measurements at temperature varying from 35 to $60^{\circ} \mathrm{C}$, as shown in Fig. 6(d). It is observed that the response increases with rising temperature, reaching a maximum at $55^{\circ} \mathrm{C}$, and then starts to decrease. This could have been caused by the denaturation of HRP or film instability at the higher temperatures.

\section{Amperometric response of the biosensor to $\mathrm{H}_{2} \mathrm{O}_{2}$}

The amperometric measurement of $\mathrm{H}_{2} \mathrm{O}_{2}$ at the enzyme electrode has been investigated and the calibration curve of the response current of the enzyme electrode to $\mathrm{H}_{2} \mathrm{O}_{2}$ concentration is shown in Fig. 7. The inset plot shows the response current of the successive addition of $0.3 \mathrm{mM} \mathrm{H}_{2} \mathrm{O}_{2}$. From Fig. 6 , it can be observed that the linear range is up to $12 \mathrm{mM}$ with a correlation coefficient $(\mathrm{R})$ of 0.9932 and then a plateau is reached gradually at higher $\mathrm{H}_{2} \mathrm{O}_{2}$ concentrations. The biosensor has a good detection limit of $0.014 \mathrm{mM}$ (signal-tonoise $=3$ ), a high sensitivity of $22.42 \mathrm{nA} / \mathrm{mM}$ and a short response time (within $\sim 4 \mathrm{~s}$ ). 

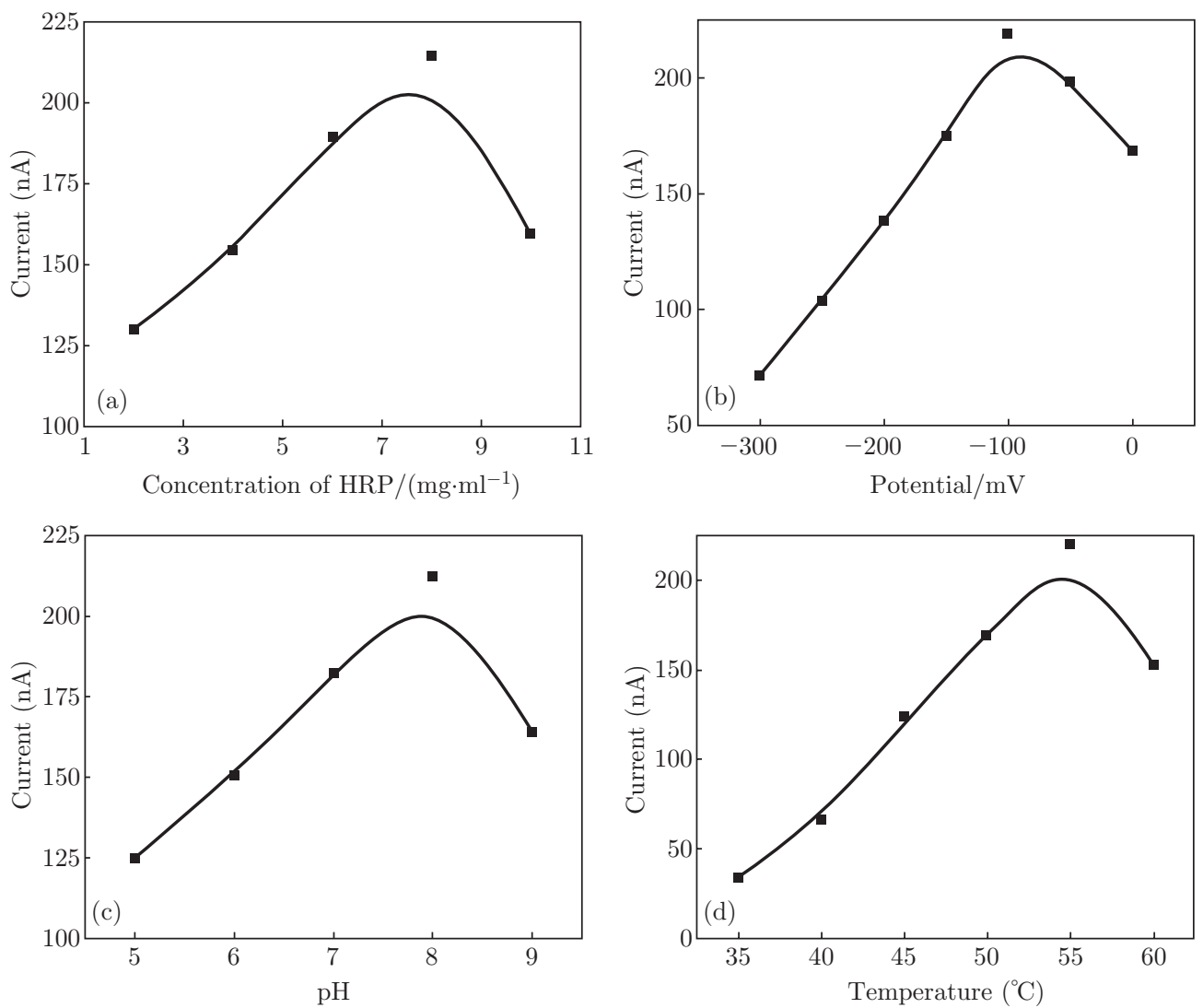

Fig. 6 (a) Effect of HRP concentration on the enzyme electrode in $10 \mathrm{mM}$ PBS solution (pH=8.0); (b) Effect of the applied potential on the amperometric response of the enzyme electrode to $12 \mathrm{mM} \mathrm{H}_{2} \mathrm{O}_{2}$ in $10 \mathrm{mM} \mathrm{PBS}$ solution (pH=8.0); (c) Effect of $\mathrm{pH}$ on the amperometric response of $12 \mathrm{mM} \mathrm{H}_{2} \mathrm{O}_{2}$ in $10 \mathrm{mM}$ PBS solution at an applied potential of -100 $\mathrm{mV}$ vs. $\mathrm{Ag} / \mathrm{AgCl}$; and (d) Effect of temperature on the amperometric response of $12 \mathrm{mM} \mathrm{H}_{2} \mathrm{O}_{2}$ in $10 \mathrm{mM} \mathrm{PBS}$ solution (pH=8.0) at an applied potential of $-100 \mathrm{mV}$ vs. $\mathrm{Ag} / \mathrm{AgCl}$.

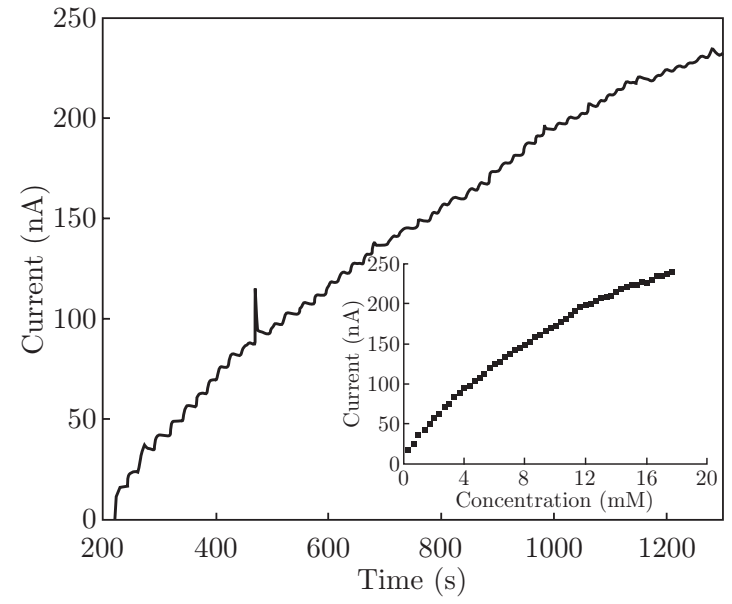

Fig. 7 Typical current-time responses obtained with enzyme electrode at an applied potential $-100 \mathrm{mV}$ to successive analyte addition in a stirred $10 \mathrm{mM} \mathrm{PBS}(\mathrm{pH}=8.0)$. The calibration curve corresponding to the current response of different concentration of $\mathrm{H}_{2} \mathrm{O}_{2}$ is given as inset.

The apparent Michaelis-Menten constant $\left(\mathrm{K}_{\mathrm{m}}^{\mathrm{app}}\right)$, which gives an indication of the enzyme-substrate kinetics, can be calculated from the electrochemical ver- sion of the Lineweaver-Burk equation $[35,36]$ :

$$
\frac{1}{I_{\mathrm{ss}}}=\frac{I}{I_{\max }}+\frac{K_{\mathrm{m}}^{\mathrm{app}}}{I_{\max }^{\mathrm{c}}}
$$

Where $I_{\mathrm{ss}}$ is the steady-state current after the addition of substrate, $\mathrm{c}$ is the bulk concentration of the substrate and $I_{\max }$ is the maximum current measured under saturated substrate condition. $K_{\mathrm{m}}^{\mathrm{app}}$ was determined by analysis of the slope and intercept for the plot of the reciprocals of the cathodic current versus $\mathrm{H}_{2} \mathrm{O}_{2}$ concentration. The apparent Michaelis-Menten constant $K_{\mathrm{m}}^{\mathrm{app}}$ in the present study is calculated to be $1.4 \mathrm{mM}$. This value is much smaller than reported in earlier work [34], indicating that the present electrode exhibits a higher affinity for $\mathrm{H}_{2} \mathrm{O}_{2}$. In Table 1 the analytical performance of this biosensor is compared with that of other biosensors in prior studies. The analytical characteristics of the enzyme electrode indicate that the immobilization of HRP mentioned above appears to be beneficial to the enhancement of the biosensor performance.

\section{Reproducibility, selectivity and recovery studies}

The reproducibility of the developed biosensor has 
Nano-Micro Lett. 3 (2), 91-98 (2011)/http://dx.doi.org/10.3786/nml.v3i2.p91-98

Table 1 Comparison of the analytical performance of the HRP based hydrogen peroxide biosensors.

\begin{tabular}{|c|c|c|c|c|c|}
\hline Electrode & $\mathrm{RT}(\mathrm{s})$ & Linear Range & Detection Limit & Sensitivity & Ref. \\
\hline $\mathrm{P}(\mathrm{GMA}-\mathrm{co}-\mathrm{VFc})$ & 4 & $2-30 \mathrm{mM}$ & $2.6 \times 10^{-6} \mathrm{M}$ & $10 \mathrm{nA} / \mathrm{mM}$ & {$[36]$} \\
\hline $\mathrm{ZrO}_{2}$ & 10 & $0.02-9.45 \mathrm{mM}$ & $2 \times 10^{-6} \mathrm{M}$ & - & {$[37]$} \\
\hline $\mathrm{Fe}_{3} \mathrm{O}_{4} /$ Dextran & 10 & $2 \times 10^{-2}-0.68 \mathrm{mM}$ & $0.078 \times 10^{-6} \mathrm{M}$ & - & {$[38]$} \\
\hline $\mathrm{Ti} / \mathrm{TiO}_{2} / \mathrm{Au}$ & 5 & $0.05-4 \times 10^{-2} \mathrm{mM}$ & $2 \times 10^{-6} \mathrm{M}$ & $1.75 \mu \mathrm{A} / \mathrm{mM}$ & {$[39]$} \\
\hline $\mathrm{Ch} / \mathrm{NiFe}_{2} \mathrm{O}_{4}$ & 4 & $0.3-12 \mathrm{mM}$ & $0.0014 \mathrm{mM}$ & $22 \mathrm{nA} / \mathrm{mM}$ & This work \\
\hline
\end{tabular}

$\mathrm{RT}$, response time; $\mathrm{P}(\mathrm{GMA}-\mathrm{co}-\mathrm{VFc})$, poly(glycidyl methacrylate-co-vinylferrocene); Ch, chitosan.

been investigated. Results show that the current response to $5 \mathrm{mM} \mathrm{H}_{2} \mathrm{O}_{2}$ is not lowered after the biosensor has been tested continuously for 20 times. To evaluate the electrode-to-electrode reproducibility, 5 enzyme electrodes were prepared under the same conditions independently. The R.S.D. (3.8\%) obtained with the present method indicates an acceptable electrode-toelectrode reproducibility. The selectivity of this $\mathrm{H}_{2} \mathrm{O}_{2}$ biosensor was evaluated by $\mathrm{H}_{2} \mathrm{O}_{2}$ detection in the presence of some potentially coexisting compounds of $\mathrm{H}_{2} \mathrm{O}_{2}$ in biological systems, including uric acid and ascorbate. Experimental results revealed that $0.1 \mathrm{mM}$ ascorbate, and $0.1 \mathrm{mM}$ uric acid would not cause observable interference in the amperometric determination of $2 \mathrm{mM}$ $\mathrm{H}_{2} \mathrm{O}_{2}$. Therefore, this $\mathrm{H}_{2} \mathrm{O}_{2}$ biosensor demonstrates good selectivity.

To demonstrate the analytical applicability of the biosensors, the recoveries of four $\mathrm{H}_{2} \mathrm{O}_{2}$ samples have been determined by the standard adding method. The results are satisfactory. As listed in Table 2, the recovery rate is in the range $95-101 \%$.

Table 2 Recovery studies of biosensor for determining $\mathrm{H}_{2} \mathrm{O}_{2}$.

\begin{tabular}{cccc}
\hline $\mathrm{C}_{\text {original }}(\mathrm{mM})$ & $\mathrm{C}_{\text {added }}(\mathrm{mM})$ & $\mathrm{C}_{\text {found }}(\mathrm{mM})$ & Recovery $(\%)^{*}$ \\
\hline 2.5 & 0.5 & 3.02 & 101.0 \\
5.0 & 1.0 & 5.88 & 98.0 \\
7.5 & 2.5 & 9.76 & 97.6 \\
10.0 & 5.0 & 14.27 & 95.1 \\
\hline
\end{tabular}

*Recovery $(\%)=$ Cfound $/($ Coriginal + Cadded $)$.

\section{Conclusions}

In this investigation, we have fabricated a new hydrogen peroxide biosensor based on the immobilization of $\mathrm{HRP}$ into the $\mathrm{NiFe}_{2} \mathrm{O}_{4} /$ chitosan nanocomposite. The experimental results clearly demonstrate that the immobilized HRP possesses excellent catalytic ability and well-retained activity. The developed biosensor is characteristic by its outstanding sensing performance, such as rapid response, wide linear range, and high sensitivity under optimum conditions.

\section{Acknowledgments}

The authors are thankful to the Fatih University, Research Project Foundation (Contract no: P500209022), Scientific and Technological Research Council of Turkey (TÜBİTAK) (Project no:110T487) and TURKEY Prime Ministry State Planning Organization.

\section{References}

[1] E. C. Hurdis and J. H. Romeyn, Anal. Chem. 26, 320 (1954). http://dx.doi.org/10.1021/ac60086a016

[2] S. Hanaoka, J. M. Lin and M. Yamada, Anal. Chim. Acta. 426,57 (2001). http://dx.doi.org/10.1016/ S0003-2670(00) 01181-8

[3] L. S. Zhang and G. T. F. Wong, Talanta 48, 1031 (1999). http://dx.doi.org/10.1016/ S0039-9140 (98) 00312-9

[4] C. Matsubara, N. Kawamoto and K. Takamura, Analyst 117, 1781 (1992). http://dx.doi.org/10.1039/ an9921701781

[5] Y . Xiao, H. X. Ju and H. Y. Chen, Anal. Biochem. 278, 22 (2000). http://dx.doi.org/10.1006/abio. 1999.4360

[6] L. Qian and X. Yang, Talanta 68, 721 (2006). http:// dx.doi.org/10.1016/j.talanta. 2005.05.030

[7] P. He and N. Hu, Electroanalysis 16, 1122 (2004). http://dx.doi.org/10.1002/elan.200403000

[8] M. Senel and M. F. Abasıyanık, Electroanalysis 22, 1765 (2010). http://dx.doi.org/10.1002/elan. 200900644

[9] S. Mahiuddin, A. Renoncourt, P. Bauduin, D. Touraud and W. Kunz, Langmuir 21, 5259 (2005). http://dx. doi.org/10.1021/la047161r

[10] M. Şenel, A. Coşkun, M. F. Abasıyanık and A. Bozkurt, Chemical Papers, 64, 1 (2010). http://dx. doi.org/10.2478/s11696-009-0103-x

[11] P. B. Beata, M. Jan and L. Andrzej, Electrochim. Acta. 5, 12173 (2006). http://dx.doi.org/10.1016/ j.electacta.2005.03.084

[12] K. Uzun, E. Çevik, M. Şenel, H. Sözeri, A. Baykal, M. F. Abasıyanık and M. S. Toprak, J. Nanopart. 10, 3057 (2010). http://dx.doi.org/10. 1007/s11051-010-9902-9 
[13] A. G. Hens, J. M. F. Romero and M. P. A. Caballos, Trends Anal. Chem. 27, 394 (2008). http://dx.doi. org $/ 10.1016 / j$.trac.2008.03.006

[14] G. Zhao, J. J. Xu and H. Y. Chen, Electrochem. Commun. 8, 148 (2006). http://dx.doi.org/10.1016/j. elecom.2005.11.001

[15] T. Zhang, B. Z. Tian, J. L. Kong, P. Y. Yang and B. H. Liu, Anal. Chim. Acta 489, 199 (2003). http://dx . doi.org/10.1016/S0003-2670(03)00758-X

[16] A. Vijayalakshmi, Y. Tarunashree, B. Baruwati, S. V. Manorama, B. L. Narayana, R. E. C. Johnson and N. M. Rao, Biosens. Bioelectron. 23, 1708 (2008). http: // dx.doi.org/10.1016/j.bios. 2008.02.003

[17] A. Kaushik, R. Khan, P. R. Solanki, P. Pandey, J. Alam, S. Ahmad and B. D. Malhotra, Biosens. Bioelectron. 24, 676 (2008). http://dx.doi.org/10.1016/j. bios.2008.06.032

[18] S. Qu, J. Wang, J. L. Kong, P. Y. Yang and G. Chen, Talanta 71, 1096 (2007). http://dx.doi.org/ $10.1016 / j$.talanta. 2006.06.003

[19] D. G. Zhang, Z. W. Tong, G. Y. Xu, S. Z. Li and J. J. Ma, Solid State Sci. 11, 113 (2009). http://dx.doi. org/10.1016/j.solidstatesciences . 2008.05.001

[20] A. E. G. Cass, G. Davis, G. D. Francis and H. A. O. Hill, Anal. Chem. 56, 667 (1984). http://dx.doi.org/ 10.1021/ac00268a018

[21] Y. Kinemuchi, K. Ishizaka, H. Suematsu, W. H. Jiang and K. Yatsui, Thin Solid Films 407, 109 (2002). http://dx.doi.org/10.1016/ S0040-6090 (02) 00021-4

[22] A. Baykal, N. Kasapoglu, Yuksel Koseoglu, M. S. Toprak and H. Bayrakdar, J. Alloys Comp. 464, 514 (2008). http://dx.doi.org/10.1016/j.jallcom . 2007.10 .041

[23] L. Luo, Q. Li, Y. Xu, Y. Ding, X. Wang, D. Deng and Y. Xu, Sensors and Actuators B 145, 293 (2010). http://dx.doi.org/10.1016/j.snb.2009.12.018

[24] J. D. Liaso, S. P. Lin and Y. T. Wu, Biomacromolecules 6, 392 (2005). http://dx.doi.org/10. $1021 / \mathrm{bm} 0494951$

[25] R. Khan, A. Kaushink, P. R. Solanki, A. A. Ansari, M. K. Pandey and B. D. Malhotra, Anal. Chim. Acta. 616, 207 (2008). http://dx.doi.org/10.1016/j.aca. 2008.04 .010
[26] O. Carp, L. Patron and A. Reler, Mater. Chem. Phys. 101, 142 (2007). http://dx.doi.org/10.1016/ j.matchemphys . 2006.03.002

[27] N. Kasapoglu, A. Baykal, Y. Koseoglu and M. S. Toprak, Scripta Mater. 57, 441 (2007). http://dx. doi.org/10.1016/j.scriptamat.2007.04.042

[28] A. Baykal, N. Kasapoğlu, Y. Köseoğlu, A. C. Başaran, H. Kavas and M. S. Toprak, Cent. Eur. J. Chem. 6, 125 (2008). http://dx.doi.org/10.2478/ s11532-007-0070-4

[29] A. M. El Sayed, Ceram. Int. 28, 363 (2002). http:// dx.doi.org/10.1016/S0272-8842(01)00103-1

[30] A. Baykal, N. Kasapoglu,Y. Koseoglu, M. S. Toprak and H. Bayrakdar, J. Alloys Comp. 464, 514 (2008). http://dx.doi.org/10.1016/j.jallcom. 2007.10 .041

[31] T. Wejrzanowski, R. Pielaszek, A. Opalinska, H. Matysiak, W. jkowski and K. J. Kurzydłowski, Appl. Surf. Sci. 253, 204 (2006). http://dx.doi.org/10. 1016/j.apsusc. 2006.05.089

[32] R. Pielaszek, "Analytical expression for diffraction line profile for polydispersive powders", in: Proceedings of the XIX Conference, Appl. Crystallography, World Scientific 2004, ISBN 981-238-761-8.

[33] H. L. Zhang, X. Z. Zou, G. S. Lai, D. Y. Han and F. Wang, Electroanalysis 19, 1869 (2007). http://dx. doi.org/10.1002/elan.200703942

[34] Z. Tong, R. Yuan, Y. Chai, Y. Xie and S. Chen, J. Biotechnol. 128, 567 (2007). http://dx.doi.org/10. 1016/j.jbiotec. 2006.12.008

[35] R. A. Kamin and G. S. Willson, Anal. Chem. 52, 1198 (1980). http://dx.doi.org/10.1021/ac50058a010

[36] M. Senel, E. Cevik and M. F. Abasıyanık, Sensors and Actuators B 145, 444 (2010). http://dx.doi.org/10. 1016/j.snb.2009.12.055

[37] Z. Tong, R. Yuan, Y. Chai, Y. Xie and S. Chen, J. Biotech. 128, 567 (2007). http://dx.doi.org/10. 1016/j.jbiotec. 2006.12.008

[38] Hai-Li Zhang, G. Lai, D. Han and A.Yu, Anal. Bioanal. Chem. 390, 971 (2008).

[39] A. K. M. Kafi, G. Wu and A. Chen, Biosens. Bioelectron. 24, 566 (2008). http://dx.doi.org/10.1016/j. bios.2008.06.004 